\title{
LIPID PEROXIDATION IN PLANT CELLS, ITS PHYSIOLOGICAL ROLE AND CHANGES UNDER HEAVY METAL STRESS
}

\author{
EWA SKÓRZYŃSKA-POLIT \\ Department of Plant Physiology, Maria Curie-Skłodowska University, Lublin \\ Akademicka 19, 20-033 Lublin, Poland \\ e-mail: Ewa.Skorzynska@umcs.lublin.pl
}

(Received: March 29, 2006. Accepted: August 22, 2006)

\begin{abstract}
Lipid peroxidation, which is a natural and essential process, can occur in a non-enzymatic and/or enzymatic way in plant cells. Some of its products have cytotoxic effects on cells, but others function as plant effectors. The lipid peroxidation in plants exposed to heavy metal stress depends on the metal, plant organ, plant species and its genotype.
\end{abstract}

KEY WORDS: heavy metal stress, lipid peroxidation, lipoxygenase.

\section{INTRODUCTION}

In plant cells free fatty acids peroxidation can occur both in a non-enzymatic and enzymatic way with lipidhydroperoxides (LOO) formed as by-products. Enzymatic lipid peroxidation is catalysed by lipoxygenases (LOXs; EC 1.13.11.12). They are a large family of enzymes widely spread in animal and plant kingdoms and in fungi. They contain non-heme iron in the active center, but manganese was also found in LOX from the fungus Gäumannomyces graminis (Su and Oliw 1998). LOX strongly prefers free fatty acids as substrates, but its activity in polyunsaturated fatty acids (PUFAs) esterified to phospholipids and with PUFAs esterified in neutral lipids such as triglycerides was also found (Feussner and Wasternack 2002). The enzymes catalyze the dioxygenation of the long chain of fatty acids containing cis, cis-1,4-pentadiene structure such as linoleic and $\alpha$-linolenic acids, and lipid hydroperoxides are formed, which are then converted to various secondary compounds (Feussner and Wasternack 2002). In non-enzymatic processes, reactive oxygen species (ROS) formed in different cell compartments (especially superoxide radical $\mathrm{O}_{2}{ }^{\circ}$ ) and transition metal ions are engaged in the initiation of lipid peroxidation (Kappus 1985). Non-enzymatic lipid peroxidation starts after hydrogen abstraction from an unsaturated fatty acid. A lipid radical is formed and after addition of molecular oxygen a radical chain reaction can occur (Kappus 1985). Peroxyl radicals (LOO*) generated as intermediates in the course of an enzymatic lipid peroxidation are transformed within the enzyme complex to corresponding anions $\left(\mathrm{LOO}^{-}\right)$loosing their reactivity, while peroxyl radicals generated in non-enzymatic reactions are not deactivated (Spiteller 2003). They react with molecules in their close vicinity causing changes in the molecular structure of biological molecules, which finally may lead to cell death.

The objective of this minireview is to discuss the role of lipid peroxidation in the physiology of plants and its changes in plants under heavy metal stress.

\section{LOX - occurrence and function}

Localization of LOX has been carried out using immunological techniques, DNA sequence or $L O X$ expression analyses. The latter allowed determination of the number of genes for LOX and their localization in cells for some plants. For example, at least four LOXs were found in Arabidopsis thaliana genome and their sequence showed that LOX1 was localized in cytoplasm, while LOX2 was in chloroplasts (Bell et al. 1995; Creelman and Mullet 1997). Recently, LOX occurrence in these compartments of Arabidopsis thaliana leaves has been confirmed using immunogold technique (Skórzyńska-Polit et al. 2006).

LOXs are present in all plant organs. Table 1 summarizes LOX occurrence and methods which were used to localize the enzyme.

In soybean leaves vegetative LOX such as VLXA, B, $\mathrm{C}$ were immunolocalized in the cytosol of bundle sheath, paraveinal mesophyll while VLXD in the vacuoles of these cells (Fischer et al. 1999). The immunogold method also revealed localizations of LOX in anther cells (Szczuka et al. 2006). $L O X$ is differently expressed in individual parts of plant; in Arabidopsis the maximum of $L O X 1$ expression was shown in roots and young seedlings, but the transcripts were also found in leaves and inflorescences (Melan et al. 1993). 
TABLE 1. Some examples of LOX localization in the individual parts of plants.

\begin{tabular}{|c|c|c|}
\hline Part of plants & Methods of examination & References \\
\hline $\begin{array}{l}\text { - soybean pod } \\
\text { - soybean seeds } \\
\text { - barley grains }\end{array}$ & $\begin{array}{l}\text { - immunolocalization } \\
\text { - primary structure of LOX, } \\
\text { - changes in genetic material } \\
\text { - expression of LOX isoenzymes }\end{array}$ & $\begin{array}{l}\text { - Dubbs and Grimes } 2000 \\
\text { - Shibata et al. } 1987 \\
\text { - Lima de Carvalho et al. } 1999 \\
\text { - Schmitt and van Mechelen } 1997\end{array}$ \\
\hline tomato fruits & $\begin{array}{l}\text { - the activity and localization of LOX } \\
\text { - isoforms of LOX }\end{array}$ & $\begin{array}{l}\text { - Suurmeijer et al. } 1998 \\
\text { - Smith et al. } 1997\end{array}$ \\
\hline $\begin{array}{l}\text { - flowers (rose petals) } \\
\text { - inflorescences of A. thaliana }\end{array}$ & $\begin{array}{l}\text { - expression of cDNA } \\
\text { - expression of } L O X 1\end{array}$ & $\begin{array}{l}\text { - Fukuchi-Mizutani et al. } 2000 \\
\text { - Melan et al. } 1993\end{array}$ \\
\hline potato tubers & accumulation of LOX transcripts & Kolomiets et al. 2001 \\
\hline $\begin{array}{l}\text { - potato roots } \\
\text { - roots of } A . \text { thaliana }\end{array}$ & $\begin{array}{l}\text { - accumulation of LOX transcripts } \\
\text { - expression of } L O X 1\end{array}$ & $\begin{array}{l}\text { - Kolomiets et al. } 2001 \\
\text { - Melan et al. } 1993\end{array}$ \\
\hline - leaves of A. thaliana & - expression of $L O X 1$ & - Melan et al. 1993 \\
\hline young seedlings of $A$. thaliana & expression of $L O X 1$ & Melan et al. 1993, 1994 \\
\hline
\end{tabular}

Moreover, $L O X$ can also differ in their spatial and temporal expression (Melan et al. 1994; Schmitt and van Mechelen 1997). LOX occurs in the cytosol and vacuoles as vegetative storage proteins termed VSPs (Porta and Rocha-Sosa 2002). The enzyme was found in mitochondria (Braidot et al. 2004), chloroplasts (Schaffrath et al. 2000), associated with microsomal membranes (Todd et al. 1990), plasma membrane (Vianello et al. 1995; Braidot et al. 2003, ) in inner exine of pollen grain and in the places connecting exine layers of the neighbouring pollen grain (Szczuka et al. 2006).

In plants multiple isoforms of lipoxygenases have been detected, which can be distinguished by differences in their properties, kinetic parameters, optimum $\mathrm{pH}$ for their activity, substrate and product specificity, tissue-specific or subcellular localization, and synthesis at the particular developmental stages (Ferrie et al. 1994; Royo et al. 1996; Hughes et al. 1998; Fuller et al. 2001). They can also fulfil various functions in plants. Vegetative LOXs (VLXs) in soybean are hypothesized to function in nitrogen storage and partitioning. They may serve as vegetative storage proteins, transiently storing nitrogen in the paraveinal mesophyll cell layer prior to its redistribution to vegetative or reproductive sink tissues. Although VLXD and VLXC have roles in nitrogen storage they are enzymatically active (Fischer et al. 1999). On the other hand LOX is found to be engaged in the mobilization of storage lipids during germination (Feussner et al. 1997). The enzyme in dry soybean seeds has a direct impact on the level of protease inhibitors and their activity (Lima de Carvalho et al. 1999). LOX is believed to mediate the formation of superoxide anion in senescent plants (Lynch and Thompson 1984). Other functions of LOX including stress responses and pathogen defense were presented earlier by Rosahal (1996) or Porta and Rocha-Sosa (2002).

\section{Physiological significance of the lipid peroxidation}

Nucleic acids analyses allow a preliminary localization of LOX on subcellular level, but in order to confirm or explain the physiological roles of individual isoforms of LOX it is necessary to apply immunological techniques and determine the enzyme activity.
Depending on oxygenation of hydrocarbon backbone at carbon atom 9 or at C-13, plant LOXs are classified as 9-LOX or 13-LOX, respectively. Such oxygenation leads to the $9(\mathrm{~S})$ - and the 13(S)-hydroperoxy derivatives of PUFAs (Gardner 1995). These compounds are subsequently metabolized in the lipoxygenase pathway in which four major metabolic routes and some other reactions for hydroperoxide metabolism have been characterized (for details see Feussner and Wasternack 2002). In the LOX pathway a lot of compounds are formed which are engaged in plant metabolism. Some of them were shown to function in plant defense reaction such as pathogen infection (Gomi et al 2002) or wounding (Kim et al. 2003). When plants are damaged by insects, the amount of volatiles normally released by an intact plant increases significantly. These volatiles are qualitatively and/or quantitatively different from those emitted by undamaged or mechanically wounded plants (for details see Porta and Rocha-Sosa 2002). Both hydroperoxides (9S- and 13S-hydroperoxy fatty acids) exhibit sporogenic effects on Aspergillus spp. and differentially modulate aflatoxin pathway gene transcription in the Aspergillus/seed interaction (Burow et al. 2000). Srinivas Reddy et al. (2000) found that 9-hydroperoxy fatty acid derived from linoleic acid is a major LOX product formed in control plants, and 9-hydroperoxy fatty acid derived from $\alpha$-linolenic acid is the major product formed in potato tubers in response to injury or infection with Rhizoctonia bataticola. They proposed that lipoxygenase metabolites of octadecadienoic acid (linoleic acid) may be involved in physiological responses under control conditions, while octadecatrienoic acid ( $\alpha$-linolenic acid) metabolites are mediating the defense responses. Jasmonic acid and related compounds are essential signals and they may also induce phytoalexin synthesis (Feussner and Wasternack 2002). LOX-dependent peroxidative pathway has also been shown to regulate hypersensitive programmed cell death in plants (Montillet et al. 2002).

Although LOXs play a role in senescence (Lynch and Thompson 1984; He et al. 2002) in senescing leaves of Arabidopsis thaliana a dominant role of non-enzymatic lipid peroxidation was shown (Berger et al. 2001). In the 
non-enzymatic reaction lipid peroxides are unstable and decompose to form a complex series of breakdown products that display a wide variety of damaging actions. For example, aldehydic molecules generated during lipid peroxidation have been implicated as causative agents in cytotoxic processes because they exhibit a direct reactivity with biomolecules (Uchida 2003). Polyunsaturated fatty acid peroxides generate malondialdehyde (MDA) and hydroxyalkenals (HAEs) (Kappus 1985; Uchida 2003). One of HAEs is known to be the major aldehyde produced during peroxidation of such fatty acids as linoleic acid and arachidonic acid. Another important reactive aldehyde - MDA, formed from linolenic acid, occurs in biological systems in various covalently bound forms and forms a variety of adducts with lysine residues of proteins or with amines containing headgroups of phospholipids (Uchida 2003).

Phytoprostanes are also formed non-enzymatically from linolenic acid. These compounds belong to a novel family of plant effectors, and their levels increase in a variety of conditions associated with enhanced free radicals generation (Thoma et al. 2003). $B_{1}$-phytoprostanes $\left(\mathrm{PPB}_{1}\right)$ are structurally related to jasmonates and their biological effects appear to be qualitatively similar to jasmonic acid (JA) or methyl jasmonate (JaMe). However, it has also been shown that biological activities of $\mathrm{JA} / \mathrm{JaMe}$ and $\mathrm{PPB}_{1}$ differ in various bioassay systems (Thoma et al. 2003; Loeffler et al. 2005).

Barclay and McKersie (1994) showed that the presence of free fatty acids in a model membrane increased lipid degradation and altered the formation of peroxidation products. They suggested that accumulation of free fatty acids under a stress had a number of deleterious consequences, but the effect on the membrane was various depending on the type of the free fatty acid that was accumulated. An increase in the concentration of free palmitic acid reduced the production of the aldehydes detected by the tiobarbituric acid, but enhanced the production of fluorescent products. Conversely, increased concentration of linolenic acid increased aldehyde production and reduced the formation of fluorescent products.

\section{Lipid peroxidation in plants under heavy metal stress}

LOX activity may be changed under both abiotic and biotic stresses (Hildebrand et al. 1988; Peever and Higgins 1989; Melan et al. 1993; Leone et al. 2001). In literature there are a few data about the effect of heavy metals on LOX occurrence and activity. In lupine roots lead stimulated the activity of most lipoxygenase isoenzymes and induced one additional isoenzyme (Rucińska and Gwóźdź 2005). The membrane-bound LOX activity was unchanged in the roots of wheat growing under $\mathrm{Cu}$ deficiency (Quartacci et al. 2001). The enzyme activity increased in the leaves of plants exposed to $\mathrm{Fe}, \mathrm{Cd}, \mathrm{Cu}, \mathrm{Pb}$ both in short-time and long-time experiments (Somashekaraiah et al. 1992; Gallego et al. 1996, Bhattacharjee 1997; Skórzyńska-Polit and Krupa 2003, 2005; Djebali et al. 2005). It was strongly enhanced by transition metals such as $\mathrm{Fe}$ and $\mathrm{Cu}$ in comparison with plants exposed to Cd (Gallego et al. 1996; Skórzyńska-Polit and Krupa 2003). In Arabidopsis thaliana plants, an increase in the activity of two LOX isoforms depended on the kind of metal as well as on the time of plants exposure to Cd or Cu (Skórzyńska-Polit and Krupa 2003). Moreover, a low level of enzymatic protein was found in these plants and additional LOX protein band appeared under high $\mathrm{Cu}$ excess (Skórzyńska-Polit et al. 2005). LOX activity increased depending on the metal concentration in germinating seedlings of Phaseolus vulgaris treated with $\mathrm{Cd}$, and the enzyme activity was much higher on 6th than on 4th day of germination, but it was not correlated with the level of lipid peroxides in these leaves (Somashekaraiah et al. 1992). Similar results were found by Skórzyńska-Polit and Krupa (2005) in young plants of Phaseolus coccineus exposed to $\mathrm{Cd}$. In older $P$. coccineus plants exposed to $\mathrm{Cd}$, LOX activity was similar to control but non-enzymatic lipid peroxidation was higher than in control plants (Skórzyńska-Polit and Krupa 2005).

The amounts of conjugated dienes increased in Raphanus sativus growing in $\mathrm{Cu}$ excess (Sgherri et al. 2003). In A. thaliana plants under $\mathrm{Cd}$ or $\mathrm{Cu}$ stress, a high level of lipid hydroperoxides was found, especially at the highest $(100 \mu \mathrm{M}) \mathrm{Cu}$ excess (Skórzyńska-Polit et al. 2004b). However, in Cd-treated A. thaliana plants their level dependend on metal concentration (Skórzyńska-Polit et al. 2004a). In A. thaliana and $P$. coccineus exposed to $\mathrm{Cd}$ or $\mathrm{Cu}$, an elevated level of jasmonic acid was found (Maksymiec et al. 2005). This means that linolenoic acid was a main substrate for LOX and such a signal particle is formed in response to heavy metal stress.

Changes in LOX activity may be associated with losses of tertiary and secondary structures of proteins. The conformational changes of soybean LOX1 were $\mathrm{pH}$-dependent (Sudharshan et al. 2000); the enzyme lost its activity irreversibly by dissociation of proteolytic domains. LOX activity may also be dependent on redox state of the cell. The lack of enzyme activity may be also caused by liberation of iron ions located in the active center of LOX. Such iron liberation occurred when polyunsaturated fatty acids liberated from membranes exceeded a certain threshold (Spiteller 2003).

However, in most studies the level of non-enzymatic lipid peroxidation, expressed as a level of MDA, was determined in plants treated with heavy metals. The increased accumulation of lipid peroxides was measured in different plants under $\mathrm{Cd}, \mathrm{Cu}, \mathrm{Zn}, \mathrm{Fe}, \mathrm{Pb}, \mathrm{Hg}$ stress (Gallego et al. 1996; Bhattacharjee 1997; Mazhoudi et al. 1997; LozanoRodriguez et al. 1997; Verma and Dubey 2003; Cho and Park 2000; Dixit et al. 2001; Metwally et al. 2005) as well as in fern treated with arsenic (Srivastava et al. 2005). Enhanced lipid peroxidation was found in roots, stems and leaves in comparison with control (Chaoui et al. 1997; Mazhoudi et al. 1997) and it was time- and Cd concentrationdependent. It was also higher in roots than in leaves of pea (Dixit et al. 2001). Transition metals exhibited stronger stimulation of non-enzymatic lipid peroxidation than $\mathrm{Cd}$ (Gallego et al. 1996; Chaoui et al. 1997; Skórzyńska-Polit et al. 2004a, b) or than Ni (Gonnelli et al. 2001). Moreover, the copper-tolerant ecotype of Silene paradoxa did not suffer from both $\mathrm{Cu}$ and $\mathrm{Ni}$ toxicity in terms of MDA production, whereas the same did not occur in the Ni-tolerant population (Gonnelli et al. 2001). Enhanced levels of the nonenzymatic lipid peroxidation products were found in Arabidopsis thaliana plants under $\mathrm{Cd}$ and $\mathrm{Cu}$ stress (Skórzyńska-Polit et al. 2004a, b). Especially, under $\mathrm{Cu}$ excess, a metal concentration-dependent increase in MDA+HAE content was observed (Skórzyńska-Polit et al. 2004b) but in Phaseolus coccineus plants treated with $\mathrm{Cd}$ this kind of 
lipid oxygenation was limited (Skórzyńska-Polit and Krupa 2005). Similarly, no peroxidation was noticed in Cd-exposed plants and hairy roots of Daucus carota (Sanita di Toppi et al. 1999) and in roots of Phragmites australis (Ederli et al. 2004).

In plants exposed to transition metals non-enzymatic lipid peroxidation may start parallelly with the LOX activation, which results in a high level of lipid peroxides. These metals participate in forming of reactive oxygen species, which accelerate the free radical reactions and finally nonenzymatic lipid peroxidation. In plants treated with $\mathrm{Cd}$ the mechanism of lipid peroxidation seems to be different. Firstly, LOX activity is enhanced and as a result non-enzymatic peroxidation can begin.

Enhanced lipid peroxidation results in an alteration in plasma membrane integrity (Somashekaraiah et al. 1992; Bhattacharjee 1997; Verma and Dubey 2003; Rucińska and Gwóźdź 2005). In non-enzymatic lipid peroxidation a fraction of alkoxy radicals generated from linolenic acid is converted to 2,4-dienals which induce the programmed cell death (Spiteller 2003). However, it seems to switch to necrotic processes when the non-enzymatic antioxidants are intensively consumed in plant cells (Spiteller 2003). To keep lipid peroxidation under control and prevent a harmful effect of lipid peroxidation products, the antioxidative system, and especially its non-enzymatic compounds such as glutathione (GSH), ascorbate or flavonoids is responsible for their scavenging in plant cells. As long as these reducing agents are available, the amount of LOOHs is low (Spiteller 2003). GSH can directly scavenge lipid peroxyl radicals or it participates in the reaction of nucleophilic attack of GSH on hydroperoxides catalysed by glutathione $S$ -transferase (GST) (Edwards et al. 2000). The enzyme can catalyze the reduction of lipid hydroperoxides to the lesstoxic monohydroxy alcohols (Ålin et al. 1985; Edwards et al. 2000). Anthocyanins are considered to be related to GST activity (Alfenito et al. 1998). Tsuda et al. (1996) found that some anthocyanins from Phaseolus vulgaris seed coat had a strong antioxidative activity in the liposomal system and reduced the formation of MDA by UVB irradiation.

Additionally, flavonoids have phenolic groups which make them perfect scavengers and quenchers of ROS and/or lipid radicals. On the other hand, flavonoids can also chelate metals like $\mathrm{Fe}^{2+/ 3+}$ and $\mathrm{Cu}^{+/ 2+}$ (Rice-Evans et al. 1997). In in vitro experiment Kondo et al. (1992) obtained Cd-commelinin in which the complexation metal $\mathrm{Mg}^{2+}$ was replaced with $\mathrm{Cd}^{2+}$. In Arabidopsis thaliana plants exposed to $\mathrm{Cd}$ or $\mathrm{Cu}$, the enhanced activity of antioxidative system was measured and the antioxidative response of plants was stronger under $\mathrm{Cu}$ - than $\mathrm{Cd}$ stress (Skórzyńska-Polit et al. 2004a, b).

\section{CONCLUSIONS}

Both enzymatic and non-enzymatic lipid peroxidations are natural and essential processes occurring in plant cells. Some products of lipid peroxidation have cytotoxic effects on the cells, but some others are plant effectors. The lipid peroxidation in plants exposed to heavy metal stress depends on the kind of metal, individual parts of plants, plant species or genotype. When plants are exposed to transition metals the lipid peroxidation is especially intensive. This is caused by enhanced LOX activity and/or parallel production of reactive oxygen species $\left(\mathrm{O}_{2}{ }_{2}\right)$ which results in free radical reactions. Lipid peroxidation is controlled in plant cells by antioxidative systems such as glutathione S-transferase, superoxide dismutase, anthocyanins and GSH.

\section{ACKNOWLEDGEMENTS}

This paper is dedicated to prof. dr hab. Tadeusz Baszyński on the occasion of his 80th birthday.

\section{LITERATURE CITED}

ALFENITO M.R., SOUER E., GOODMAN C.D., BUELL R., MOL J., KOES R., WALBOT V. 1998. Functional complementation of anthocyanin sequestration in the vacuole by widely divergent glutathione S-transferases. Plant Cell 10: 1135-1149.

ÅLIN P., DANIELSON H., MANNERVIK B. 1985. 4-Hydroxyalk-2-enals are substrates for glutathione transferase. FEBS Lett. 179: 267-270.

BARCLAY K.D. MCKERSIE B.D. 1994. Peroxidation reactions in plant membranes: Effects of free fatty acids. Lipids 29: 877-882.

BHATTACHARJEE S. 1997. Membrane lipid peroxidation, free radical scavengers and ethylene evolution in Amaranthus as affected by lead and cadmium. Biol. Plant. 40: 131-135.

BELL E., CREELMAN R.A., MULLET J.E. 1995. A chloroplast lipoxygenase is required for wound-induced jasmonic acid accumulation in Arabidopsis. Proc. Natl. Acad. Sci USA 92: 8675-8679.

BERGER S., WEICHERT H., PORZEL A., WASTERNACK C., KÜHN H., FEUSSNER I. 2001. Enzymatic and non-enzymatic lipid peroxidation in leaf development. Biochim. Biophys. Acta 1533: 266-276.

BRAIDOT E., MICOLINI S., RISSO A., MACRI F., VIANELLO A. 2003. Immunochemical evidence for the presence of a lipoxygenase 1 in isolated plasma membranes from soybean cotyledons. Plant Sci. 164: 9-16.

BRAIDOT E., PETRUSSA E., MICOLINI S., TUBARO F., VIANELLO A., MACRI F. 2004. Biochemical and immunochemical evidences for the presence of lipoxygenase in plant mitochondria. J. Exp. Bot. 55: 1655-1662.

BUROW G.B., GARDNER H.W., KELLER N.P. 2000. A peanut seed lipoxygenase responsive to Aspergillus colonization. Plant Molec. Biol. 42: 689-701.

CHAOUI A., MAZHOUDI S., GHORBAL M.H., EL FERJANI E. 1997. Cadmium and zinc induction of lipid peroxidation and effects on antioxidant enzyme activities in bean (Phaseolus vulgaris L.). Plant Sci. 127: 139-147.

CHO U.-H., PARK J.-O. 2000. Mercury-induced oxidative stress in tomato seedlings. Plant Sci. 156: 1-9.

CREELMAN R., MULLET J. 1997. Biosynthesis and action of jasmonates in plants. Ann. Rev. Plant Physiol. Plant Mol. Biol. 48: 355-381.

DIXIT V., PANDEY V., SHYAM R. 2001. Differential antioxidative responses to cadmium in roots and leaves of pea (Pisum sativum L. cv. Azad). J. Exp. Bot. 52: 1101-1109.

DJEBALI W., ZARROUK M., BROUQUISSE R., EL KAHOUI S., LIMAM F., GHORBEL M.H., CHAIBI W. 2005. Ultrastructure and lipid alteration induced by cadmium in tomato (Lycopersicon esculentum) chloroplast membranes. Plant Biol. 7: 358-368.

DUBBS W.E., GRIMES H.D. 2000. The mid-pericarp cell layer in soybean pod walls is a multicellular compartment enriched in specific lipoxygenase isoforms. Plant Physiol. 123: 1281-1288 . 
EDERLI L., REALE L., FERRANTI F., PASQUALINI S. 2004. Responses induced by high concentration of cadmium in $\mathrm{Ph}$ ragmites australis roots. Physiol. Plant. 121: 66-74.

EDWARDS R., DIXON D.P., WALBOT V. 2000. Plant glutathione S-transferases: enzymes with multiple functions in sickness and in health. Trends Plant Sci. 5: 193-198.

FERRIE B.J., BEAUDOIN N., BURKHART W., BOWSHER C.G., ROTHSTEIN S.J. 1994. The cloning of two tomato lipoxygenase genes and their differential expression during tomato fruit ripening. Plant Physiol. 106: 109-118.

FEUSSNER I., BALKENHOHL T.J., PORZEL A. KÜHN H. WASTERNACK C. 1997. Structural elucidation of oxygenated storage lipids in cucumber cotyledons - implication of lipid body lipoxygenase in lipid mobilization during germination. J. Biol. Chem. 272: 21635-21641.

FEUSSNER I., WASTERNACK C. 2002. The lipoxygenase pathway. Annu. Rev. Plant Biol. 53: 275-297.

FISCHER A.M., DUBBS W.E., BAKER R.A., FULLER M.A., STEPHENSON L.C., GRIMES H.D. 1999. Protein dynamics, activity and cellular localization of soybean lipoxygenases indicate distinct functional roles for individual isoforms. Plant $\mathrm{J}$. 19: 543-554.

FUKUCHI-MIZUTANI M., ISHIGURO K., NAKAYAMA T., UTSUNOMIYA Y., TANAKA Y., KUSUMI T., UEDA T. 2000. Molecular and functional characterization of a rose lipoxygenase cDNA related to flower senescence. Plant Sci. 160: 129-137.

FULLER A.M., WEICHERT H., FISCHER M., FEUSSNER I., GRIMES D.H. 2001. Activity of soybean lipoxygenase isoforms against esterified fatty acid indicates functional specificity. Arch. Biochem. Biophys. 6: 146-154.

GALLEGO S.M., BENAVIDES M.P. TOMARO M.L. 1996. Effect of heavy metal ion excess on sunflower leaves: evidence for involvement of oxidative stress. Plant Sci. 121: 151-159.

GARDNER H.W. 1995. Biological roles and biochemistry of the lipoxygenase pathway. Hort Sci. 30: 197-205.

GOMI K., YAMAMOTO H., AKIMITSU K. 2002. Characterization of a lipoxygenase gene in rough lemon induced by Alternaria alternata. Gen. Plant Pathol. 68: 21-30.

GONNELLI C., GALARDI F., GABBRIELLI R. 2001. Nickel and copper tolerance and toxicity in three Tuscan populations of Silene paradoxa. Physiol. Plant. 113: 507-514.

HE Y., FUKUSHIGE H., HILDEBRAND D.F., GAN S. 2002. Evidence supporting a role of a jasmonic acid in Arabidopsis leaf senescence. Plant Physiol. 128: 876-884.

HILDEBRAND D.F., HAMILTON-KEMP T.R., LEGG C.S., BOOKJANS G. 1988. Plant lipoxygenases: occurrence, properties and possible functions. Curr. Topics Plant Biochem. Physiol. 7: 201-219.

HUGHES R.K., WU Z., ROBINSON D.S., HARDY D., WEST S.I., FAIRHURST S.A., CASEY R. 1998. Characterization of authentic recombinant pea-seed lipoxygenases with distinct properties and reaction mechanisms. Biochem. J. 333: 33-43.

KAPPUS H. 1985. Lipid peroxidation: mechanism, analysis, enzymology and biological relevance. In: Oxidative stress. Sies H. (ed.). Academic Press, London, pp. 273-310.

KIM E.-S., CHOI E., KIM Y., CHO K., LEE A., SHIM J., RAKWAL R., AGRAWAL G.K., HAN O. 2003. Dual positional specificity and expression of non-traditional lipoxygenase induced by wounding and methyl jasmonate in maize seedlings. Plant Mol. Biol. 52: 1203-1213.

KOLOMIETS M.V., HANNAPEL D.J., CHEN H., TYMESON M., GLADON R.J. 2001. Lipoxygenase is involved in the control of potato tuber development. Plant Cell 13: 613-626.

KONDO T., YOSHIDA K., NAKAGAWA A., KAWAI T., TAMURA H., GOTO T. 1992. Structural basis of blue-colour development in flower petals from Commelina communis. Nature 358: 515-518.
LEONE A., MELILLO M.T., BLEVE-ZACHEO T. 2001. Lipoxygenase in pea roots subjected to biotic stress. Plant Sci. 161: 703-717.

LIMA DE CARVALHO W., GORETI DE ALMEIDA OLIVEIRA M., GONÇALVES DE BARROS E., MOREIRA M.A. 1999. Lipoxygenases affect protease inhibitor levels in soybean seeds. Plant Physiol. Biochem. 37: 497-501.

LOEFFLER C., BERGER S., GUY A., DURAND T., BRINGMANN G., DREYER M., VON RAD U., DURNER J., MUELLER M.J. 2005. Â $\hat{A}_{1}$-Phytoprostanes trigger plant defense and detoxification responses. Plant Physiol. 137: 328-340.

LOZANO-RODRIGUEZ E., HERNANDEZ L.E., BONAY P., CARPENA-RUIZ R.O. 1997. Distribution of cadmium in shoot and root tissues of maize and pea plants: physiological disturbances. J. Exp. Bot. 48: 123-1287.

LYNCH D.V., THOMPSON J.E. 1984. Lipoxygenase-mediated production of superoxide anion in senescing plant tissue. FEBS Lett. 173: 251-254.

MAKSYMIEC W., WIANOWSKA D., DAWIDOWICZ A.L., RADKIEWICZ S., MARDAROWICZ M., KRUPA Z. 2005. The level of jasmonic acid in Arabidopsis thaliana and Phaseolus coccineus plants under heavy metal stress. J. Plant Physiol. 162: 1338-1346.

MAZHOUDI S., CHAOUI A., GHORBAL M.H., EL FERJANI E. 1997. Response of antioxidant enzymes to excess copper in tomato (Lycopersicon esculentum, Mill). Plant Sci. 127: 129-137.

MELAN M.A., DONG X., ENDARS M.E., DAVIS K.R., AUSUBEL F.M., PETERMAN T.K. 1993. An Arabidopsis thaliana lipoxygenase gene can be induced by pathogens, abscisic acid, and methyl jasmonate. Plant Physiol. 101: 441-450.

MELAN M.A., ENRIQUEZ A.L.D., PETERMAN T.K. 1994. The LOXI gene of Arabidopsis is temporary and spatially regulated in germinating seedlings. Plant Physiol. 105: 385-393.

METWALLY A., SAFRONOVA V.I., BELIMOV A.A., DIETZ K.-J. 2005. Genotypic variation of the response to cadmium toxicity in Pisum sativum L. J. Exp. Bot. 56: 167-178.

MONTILLET J.-L., AGNEL J.-P., PONCHET M., VAILLEAU F., ROBY D., TRANTAPHYLIDES C. 2002. Lipoxygenasemediated production of fatty acid hydroperoxides is a specific signature of the hypersensitive reaction in plants. Plant Physiol. Biochem. 40: 633-639.

PEEVER T.L., HIGGINS V.J. 1989. Electrolyte leakage, lipoxygenase, and lipid peroxidation induced in tomato leaf tissue by specific and nonspecific elicitors from Cladosporium fulvum. Plant Physiol. 90: 867-875.

PORTA H., ROCHA-SOSA M. 2002. Plant lipoxygenases. Physiological and molecular features. Plant Physiol. 130: 15-21.

QUARTACCI M.F., COSI E., NAVARI-IZZO F. 2001. Lipids and NADPH-dependent superoxide production in plasma membrane vesicles from roots of wheat grown under copper deficiency or excess. J. Exp. Bot. 52: 77-84.

RICE-EVANS C., MILLER N.J., PAPANGA G. 1997. Antioxidant properties of phenolic compounds. Trends Plant Sci. 2: 152-158.

ROSAHAL S. 1996. Lipoxygenase in plants - their role in development and stress response. Z. Naturforsch. 51c: 123-138.

ROYO J., VANCANNEYT G., PÉREZ A.G., SANZ C., STÖRMANN K., ROSAHL S., SÁNCHEZ-SERRANA J.J. 1996. Characterization of three potato lipoxygenases with distinct enzymatic activities and different organ-specific and woundregulated expression patters. J. Biol. Chem. 271: 21012$-21019$.

RUCIŃSKA R., GWÓŹDŹ E.A. 2005. Influence of lead on membrane permeability and lipoxygenase activity in lupine roots. Biol. Plant. 49: 617-619.

SANITA DI TOPPI L., LAMBARDI M., PECCHIONI N., PAZZAGLI L., DURANTE M., GABBRIELLI R. 1999. Effects of cadmium stress on hairy roots of Daucus carota. J. Plant Physiol. 154: 385-391. 
SCHAFFRATH U., ZABBAI F., DUDLER R. 2000. Characterization of RCI-1, a chloroplastic rice lipoxygenase whose synthesis is induced by chemical plant resistance activators. Eur. J. Biochem. 267: 5935-5942.

SCHMITT N.F., VAN MECHELEN J.R. 1997. Expression of lipoxygenase isoenzymes in developing barley grains. Plant Sci. 128: $141-150$.

SGHERRI C., COSI E., NAVARI-IZZO F. 2003. Phenols and antioxidative status of Raphanus sativus grown in copper excess. Physiol. Plant. 118: 21-28.

SHIBATA D., STECZKO J., DIXON J.E., HERMODSON M., YAZDANPARAST R., AXELROD B. 1987. Primary structure of soybean lipoxygenase-1. J. Biol. Chem. 262: 10080-10085.

SKÓRZYŃSKA-POLIT E., KRUPA Z. 2003. Activity of lipoxygenase in Arabidopsis thaliana - a preliminary study. Cell. Molec. Biol. Lett. 8: 279-284.

SKÓRZYŃSKA-POLIT E., DRĄŻKIEWICZ M., PAWEŁCZAK O., KRUPA Z. 2004a. Lipid peroxidation in Cd-treated Arabidopsis thaliana plants. Mat. sesji i sympozjów 53 Zjazdu PTBot. Toruń/Bydgoszcz, 44.

SKÓRZYŃSKA-POLIT E., DRĄŻKIEWICZ M., PAWEŁCZAK O., KRUPA Z. 2004b. Lipid peroxidation in Arabidopsis thaliana plants under $\mathrm{Cu}$ excess. Mat. sesji i sympozjów $53 \mathrm{Zja}$ zdu PTBot., Toruń/Bydgoszcz, errata 47.

SKÓRZYNSSKA-POLIT E., KRUPA Z. 2006. Lipid peroxidation in Cd-treated Phaseolus coccineus plants. Arch. Environ. Contam. Toxicol. 50: 482-487.

SKÓRZYŃSKA-POLIT E., PAWLIKOWSKA-PAWLĘGA B., SZCZUKA E., DRĄŻKIEWICZ M., KRUPA Z. 2006. Localization and activity of lipoxygenase in Arabidopsis thaliana plants under heavy metal stress. Plant Growth Reg. 48: 29-39.

SMITH P.K., LINFORD R., TUCKER G.A. 1997. Soluble lipoxygenase isoforms from tomato fruit. Phytochemistry 45: 453-458.

SOMASHEKARAIAH B.V., PADMAJAM K., PRASAD A.R.K. 1992. Phytotoxicity of cadmium ions on germinationing seedlings of mung bean (Phaseolus vulgaris): Involvement of lipid peroxides in chlorophyll degradation. Physiol. Plant. 85: 85-89.

SPITELLER G. 2003. The relationship between changes in the cell wall, lipid peroxidation, proliferation, senescence and cell death. Physiol. Plant. 119: 5-18.

SRINIVAS REDDY P., KUMAR T.C., NARSA REDDY M., SARADA C., REDDANNA P. 2000. Differential formation of octadecadienoic acid and octadecatrienoic acid products in control and injured/infected potato tubers. Biochim. Biophys. Acta 1483: 294-300.

SRIVASTAVA M., MA L.Q., SINGH N., SINGH S. 2005. Antioxidant responses of hyper-accumulator and sensitive fern species to arsenic. J. Exp. Bot. 56: 1335-1342.

SU C., OLIW E.H. 1998. Manganese lipoxygenase. Purification and characterization. J. Biol. Chem. 273: 13072-13079.

SUDHARSHAN E., SRINIVASULU S., APPU RAO A.G. 2000. $\mathrm{pH}$-induced domain interaction and conformational transitions of lipoxygenase-1. Biochim Biophys. Acta 1480: 13-22.

SUURMEIJER C.N.S.P., PÉREZ-GILABERT M., VAN DER HIJDEN H.T.W.M., VELDINK G.A. VLIEGENTHART J.F.G. 1998. Purification, product characterization and kinetic properties of soluble tomato lipoxygenase. Plant Physiol. Biochem. 36: 657-663.

SZCZUKA E., SKÓRZYŃSKA-POLIT E., PAWLIKOWSKA-PAWLĘGA B., SOBIESKA J., GAWRON A. 2006. Immunolocalization of lipoxygenase in the anther of Gagea lutea (L.) Ker.-Gaw. Acta Biol. Cracov. 48: 19-26.

THOMA I., LOEFFLER C., SINHA A.K., GUPTA M., KRISCHKE M., STEFFAN B., ROITSCH T., MUELLER M.J. 2003. Cyclopentenone isoprostanes induced by reactive oxygen species trigger defense gene activation and phytoalexin accumulation in plants. Plant J. 34: 363-375.

TODD J.F., PALIYATH G., THOMPSON J.E. 1990. Characteristics of a membrane-associated lipoxygenase in tomato fruit. Plant Physiol. 94: 1225-1232.

TSUDA T., SHIGA K., OHSHIMA K., KAWAKISHI S., OSAWA T. 1996. Inhibition of lipid peroxidation and the active oxygen radical scavenging effect of anthocyanin pigments isolated from Phaseolus vulgaris L. Biochem. Pharmacol. 52: 1033-1039.

UCHIDA K. 2003. 4-Hydroxy-2-nonenal: a product and mediator of oxidative stress. Progress Lipid Res. 42: 318-343.

VERMA S., DUBEY R.S. 2003. Lead toxicity induces lipid peroxidation and alters the activities of antioxidant enzymes in growing rice plants. Plant Sci. 164: 645-655.

VIANELLO A., BRAIDOT E., BASSI G., MACRI F. 1995. Lipoxygenase activity on the plasmalemma of sunflower protoplasts and its modulation. Biochim. Biophys. Acta 1255: 57-62. 